\title{
The Tangible Contribution of R\&D Spending Foreign-Owned Plants to a Host Region: a Plant Level Study of the Irish Manufacturing Sector (1980-1996)
}

\author{
Trinity Economic Paper Series \\ Technical Paper No. 99/7 \\ JEL Classification: F23, 030
}

\author{
Allan Kearns \\ Department of Economics \\ Trinity College \\ Dublin 2 \\ Ireland \\ kearnsa@tcd.ie
}

\author{
Frances Ruane* \\ Department of Economics \\ Trinity College \\ Dublin 2 \\ Ireland \\ fruane@tcd.ie
}

\begin{abstract}
Using plant level data from the Irish manufacturing sector, we explore the relationship between foreign direct investment (FDI) and economic growth in Ireland. The central question explored in this paper is whether the tangible contribution of MNC plants which undertake R\&D investment in Ireland is greater than the tangible contribution of MNC plants which undertake no $R \& D$ investment. We conclude that the scale of $R \& D$ activity in a plant is an important determinant in (i) lengthening the duration over which that plant will remain in Ireland and (ii) in improving the quality of employment created in that plant.
\end{abstract}

\footnotetext{
* Correspondence to: Professor Frances Ruane / Allan Kearns, Department of Economics, Trinity College, Dublin 2, Ireland. Tel: + 3531 6081325, fax: + 35316772503 or Email fruane@tcd.ie or kearnsa@tcd.ie.

This paper is supported by Science and Technology Division of Forfás. We gratefully acknowledge the provision of data for this study by Forfás and the help given by Marcus Breathnach and his colleagues in the Science and Technology Division in preparation of this paper. Allan Kearns also acknowledges the financial assistance of the Royal Irish Academy Social Science Research Council, Ireland. We also thank Marcus Breathnach, Holger Görg and Mary Keeney and participants at the INTECH Euroconference on Industrial Structure, Innovation Dynamics and Technology Policy (October 1998). The views expressed in this paper are the authors' and do not reflect the views of the Department of Economics, Trinity College, Dublin.
} 


\section{Introduction}

Following a period of recession, the Irish economy has enjoyed significant growth over the past decade, earning Ireland its "Celtic Tiger" nickname. This growth, both in employment and output terms, is most marked in the manufacturing sector. The contrast in employment growth is primarily with EU countries, which have seen employment in manufacturing rise by $0.5^{1}$ per cent since 1986 , while employment in the Irish manufacturing sector during the same period has risen by 5.4 per cent. A key feature of Ireland's growth has been the expansion of foreignowned plants which now account for 12 per cent of total manufacturing firms in the country and 45.5 per cent of manufacturing employment. ${ }^{2}$ The growth in employment has been concentrated in the high-tech sectors, where employment has more than doubled since 1986; these sectors in 1996 account for 62 per cent and 17.4 per cent of total manufacturing employment in foreign and Irish-owned firms respectively. ${ }^{3}$ The latest output data available (1995), show that output of foreign-owned manufacturing firms accounts for 65.2 per cent of total gross manufacturing output (CSO, 1997). In 1995, 65 per cent of national business expenditure on research and development (BERD) in Ireland was accounted for by subsidiaries of foreign multinational firms (Forfás, 1997). This contrasts sharply with estimates for other European countries: 37 per cent for Great Britain, 16 per cent for Germany and less than 10 per cent for Greece (OECD, 1998).

\footnotetext{
${ }^{1}$ Eurostat (1997) Eurostatistics, 6/1997, Eurostat (1991) Eurostatistics, 12/1991.

${ }^{2}$ Unless stated otherwise, all reported figures are based on own calculations of Forfás Employment Survey Data.

${ }^{3}$ Employment growth rates in the US and Canadian manufacturing sectors in the same period were 6.2 per cent and 7.5 per cent respectively. (OECD, 1996)
} 
The rapid growth of the Irish economy over the past decade and the simultaneous increase in (i) the number of foreign-owned plants in the high-tech sectors and (ii) the research and development (R\&D) activities of foreign-owned plants has given rise to an increased interest in the relationship between foreign direct investment (FDI) and economic growth in Ireland. The issue arises as to whether the growth is linked to the sectors in which FDI is taking place or whether the technological performance of individual plants is a significant contributory factor. In particular, an important question is whether those plants that are undertaking $R \& D$ activities in their Irish plants are contributing more to the host region relative to those plants that undertake no R\&D activities.

The exploration of plant-level technological activity in MNC plants and their contribution to the host economy is a hybrid of two literature traditions. The first relates to the internationalisation of $R \& D$ activity. Many authors have debated about the true extent of this internationalisation (Belitx and Beise, 1997, Braunerhjelm and Ekholm, 1997; OECD, 1998) and the tangible and intangible effects of this trend on host economies (Blomström and Kokko (1996) and Beise et al (1998). The second tradition are studies of the attraction of FDI to a host region (Dunning 1988) and specifically to Ireland (Ruane and Görg, 1996 and Foley and McAleese, 1991) with its subsequent effects on the Irish economy (McAleese and MacDonald (1978), Farrell and O'Loughlin (1981), Barry and Bradley (1997); Ruane and Görg (1998).

In this paper we undertake a plant-level empirical analysis of the tangible effects of MNC technological activities, focusing on $R \& D$ aspects. Specifically, we use our plant-level dataset to explore different 
measures of $R \& D$ activity undertaken by foreign-owned plants in Ireland. These empirical measures, derived from plant-level data, provide a new perspective on the extent of these R\&D activities. The central question explored in this paper is whether the tangible contribution of MNC plants which undertake $R \& D$ investment in Ireland is greater than the tangible contribution of MNC plants which undertake no R\&D investment. We conclude that R\&D-active MNC plants in Ireland have (i) a higher probability of remaining operational in Ireland for a given time period and (ii) create a higher quantity and quality of employment, relative to non$\mathrm{R} \& \mathrm{D}$ active MNC plants.

Section 2 describes our plant-level dataset. In Section 3 we compare our estimates of R\&D activities of MNCs in Ireland with the aggregate statistics provided by the OECD. In Section 4 we outline our expectations of a relationship between investment in $R \& D$ and the subsequent performance of MNC subsidiaries in Ireland. In Sections 5 and 6 we compare the survival experiences and the employment performance respectively of $R \& D$-active $M N C s$, relative to non-R\&D active MNCs. The final section contains a short summary and some conclusions.

\section{Data \& Sectoral Classification}

The data set explored here is a unique combination of two sources. The $R \& D$ data are drawn from a series of surveys of $R \& D$ performing plants, undertaken by the policy and advisory board for industrial development in Ireland (Forfás). This organisation has statutory responsibility for R\&D statistics in Ireland. For the years 1986 to 1995, the biannual surveys reported data on the population of $R \& D$ performers 
with ten or more employees in the manufacturing and internationallytraded services sectors. ${ }^{4}$ The employment data (1980-1996) are drawn from the annual employment surveys undertaken by the same agency. Similar to the R\&D data, these employment surveys cover the population of plants in the manufacturing and internationally traded service sectors. ${ }^{5}$ The employment survey data covers all plants and in matching the two Forfás surveys, we have excluded any plant with less than ten employees through the period 1980 to $1996 .^{6}$ In the analysis that follows, where a variable is not available for all of the surveys of technology in industry, we report the last year for which that variable is available. For example, when estimating the percentage of $R \& D$ spend that is invested in experimental development, we note that this information is available for the period 1986-1993 only. No information on this variable is provided in the 1995 survey.

We define an MNC plant or a foreign-owned plant as any plant where in excess of fifty percent of the equity is held by non-Irish residents - this is the classification used in both surveys. Because a plant's current (i.e., 1996) nationality only is maintained in the dataset, we are unable to take account of any changes in ownership during the period 1980-1996. ${ }^{7}$

Throughout this paper we use the OECD sectoral classification to aggregate sectors into four groups:

\footnotetext{
${ }^{4}$ The biannual surveys switched to odd number years in 1991, thereby following immediately after the 1990 survey of technology in industry. Forfás estimates a response rate close to $100 \%$ for this survey. There is an additional survey of innovation in Irish manufacturing in 1992.

${ }^{5}$ The response rate is greater than $90 \%$ for this survey (Strobl, 1996)

${ }^{6}$ Forfás was established in 1993 and involved the merger of the planning division of the Industrial Development Authority (IDA) which began its employment surveys in 1973 and the Science and Technology Division of Eolas, which began its employment surveys in 1967.

${ }^{7}$ The effect of this is that some indigenous firms which are taken over by foreign-owned firms during that period are classified as foreign firms.
} 
- High-tech: Aerospace, Computers \& Office machinery, Electronics \& Communications, Pharmaceuticals;

- Medium-High-tech: Scientific Instruments, Electrical Machinery, Motor Vehicles, Chemicals, Non-electrical machinery;

- Medium-low-tech: Shipbuilding, Rubber \& plastic equipment, Other transport equipment, Stone, clay \& glass, Non-ferrous metals, Other manufacturing, Fabricated metal products;

- Low-tech: Petroleum refining, Ferrous metals, Paper printing, Textiles and clothing, Wood \& furniture, Food beverages.

For the ISIC equivalent classification, see Appendix B in Klette (1995). We use higher-tech or higher technology sectors as a term encompassing both the high-tech and medium high-tech sectors. The use of lower-tech as a summary term refers to both the low-tech and medium low-tech sectors.

We classify a plant as being "R\&D-active" where that plant has reported at minimum an average annual $R \& D$ investment of $£ 25,000$ over the period 1986-1995. Plants with an annual mean of $£ 100,000$ or over in R\&D spend over this period are classified as "large R\&D spenders".

\section{The evolution of Irish Industrial Policy towards FDI}

Gray (1997) provides the most optimistic evaluation of the importance of FDI in the Irish economy '[I]t is probably not an exaggeration to say that the growth in foreign investment is at the heart of the Irish economic miracle.' Ruane and Görg (1998) summarise the evolution of Irish FDI policy in three steps: 
(i) An active policy of attracting FDI came into operation initially in the 1950s. Before this time FDI had been legislatively prohibited. ${ }^{8}$ The objectives of embracing a pro-FDI policy were to generate a viable manufacturing sector and to provide employment. Export-orientated foreign-owned projects in all sectors of manufacturing were eligible for fiscal and financial support, on the same basis as indigenous projects, if they located in Ireland. ${ }^{9}$

(ii) The second step occurred in the 1970s. The national industrial development agency, the IDA, became increasingly selective about the industries in which potential FDI projects should be sought. The electronics and pharmaceutical sectors were singled out as having the best global prospects for fast and sustained growth. In particular US companies were targeted as sources of these projects.

(iii) The third step involved the promotion of linkages between foreign and indigenous industry in these key sectors, and the promotion of Ireland as the European base for head-quarter and R\&D functions of MNCs. Those plants which locate these functions locally are believed to have a higher commitment to Ireland, reflected in the generation of a higher quantity and quality of employment relative to plants which locate only their production facilities in Ireland. Global companies operating in the higher technology sectors were perceived as having a larger probability of undertaking significant $R \& D$ activities relative to companies operating in the lower

\footnotetext{
${ }^{8}$ This prohibition was supported by the public perception of a link between economic dependence and the country's colonial past.

${ }^{9}$ For a discussion of policy development see White (1972) and Killeen (1975).
} 
technology sectors ${ }^{10}$, where $R \& D$ activities are not perceived as being as important globally. ${ }^{11}$

These refinements to FDI policy over time have manifested themselves in (i) a concentration of current FDI in high-tech sectors and (ii) an increased propensity for foreign-owned plants to undertake $R \& D$ activities in Ireland. We now turn to look at one explanation for the increasing concentration of FDI in high-tech sectors, namely, the higher rate of entry of foreign-owned plants into the high-tech sector.

\section{(A) Plant Entry into High-tech Sectors}

As we can see from Table 1, there was an increase of over 50 per cent in the number of foreign-owned manufacturing plants in Ireland over the period 1980-1996. This increase disguises the extensive net change in plant numbers in different sectors; ranging from over 150 per cent in the high-tech sector to less than 10 per cent in the low-tech sector. In terms of net job creation, this change in plant numbers accompanied a net increase of $22,505(32.5 \%)$ jobs in the foreign-owned plants. Mirroring the experience in plant numbers, this net increase resulted from a combination of 27,683 jobs created in both higher-tech sectors with a loss of 5,358 in both lower-tech sectors. In terms of the number of employees, the period 1980-1996 saw FDI in the higher technology sectors become the dominant form of FDI in Ireland, as the share of employment in high-tech MNCs rose from almost 15 per cent to over 30 per cent.

\footnotetext{
${ }^{10}$ One exception here is the food sector, which although classified by the OECD as a relatively lowtech sector, has a high level of R\&D expenditure in Ireland.

${ }^{11}$ de Arcos et al (1997) summarise step one as dependent FDI (an emphasis on assembly plants) and the following two steps as an evolution towards developmental FDI (an emphasis on plants which can forge linkages with indigenous industry and create high skilled employment).
} 


\section{(Table 1)}

The overall change in the number of plants is the net result of plant entry and exit. We summarise in Table 2 the entry pattern of foreignowned plants into the Irish manufacturing sector over the period 19801996. A mean annual entry rate is calculated using methodology outlined in Strobl et al (1998) and originally in Davis and Haltiwanger (1990).

The plant population size is defined in the manufacturing sector as

$$
a_{E t}=\frac{P_{E t}+P_{E t-1}}{2}
$$

where $P_{E t}$ is the number of plants in category ${ }^{12} \mathrm{E}$ at time $\mathrm{t}$ and $a_{E t}$ is the average number of plants in this category over the period t- 1 to t. The number of births is calculated as the number of plants alive in category $\mathrm{E}$ in time $\mathrm{t}$ that were not alive in category $\mathrm{E}$ in time $\mathrm{t}-1$. The birth rate is defined as follows:

$$
B_{E t}=\frac{b_{E t}}{a_{E t}}
$$

$B_{E t}$, the birth rate, is a measure of the extent of entry into an industry (1980-1996). Over this period, there was a mean annual birth rate for all plants of 4.6 per cent. Disaggregating these plants by sector, we find that the mean annual entry rate in the high-tech sector is significantly higher than those in the less technologically-sophisticated sectors.

\footnotetext{
${ }^{12}$ Examples of these categories could be sector, age category or size category.
} 


\section{(Table 2)}

\section{(B) R\&D Activity and Foreign-owned Plants in Ireland}

A key question is whether this increase in the number of plants in the high-tech sectors was accompanied by an increase in the R\&D activities of foreign-owned plants. The latest OECD report (June 1998) on the internationalisation of industrial $R \& D$ provides estimates of the importance of $R \& D$ expenditure of foreign affiliates as a percentage of total industrial $R \& D$ in a range of host economies:

\section{(Table 3)}

Ireland has the largest share of industrial $R \& D$ accounted for by foreign affiliates as shown in Table 3, by a factor of almost two. The country's unique position in terms of the scale of $R \& D$ activity accounted for by MNCs is explained by the OECD as the combination of (i) very low levels of R\&D spend by indigenous plants in the Irish manufacturing sector and (ii) the relatively large presence of foreign multinationals in the Irish manufacturing sector generally (OECD, 1998:18). The OECD also estimates the intensity of the R\&D investment by MNCs across countries. We note from Table 3 that Ireland has a lower R\&D intensity than many of the other countries, with the exception of the Netherlands (OECD, 1998:22). ${ }^{13}$ There are two possible explanations for this low intensity. Firstly, the small numbers of foreign-owned plants undertaking $R \& D$ relative to the total number of such plants in Ireland. Thus, when all foreign-owned plants are aggregated, we arrive at a relatively high total for manufacturing turnover and a relatively smaller total for R\&D spend. An alternative measure of $R \& D$ intensity would involve aggregating over only those plants that undertake R\&D expenditure. Secondly, the turnover 
figures reported by MNCs in Ireland may be artificially high relative to the true level of value added and production that takes place in Irish plants, to the extent that there they engage in profit-switching transfer pricing. ${ }^{14}$ If this is the case, our estimates of R\&D intensity would be underestimated. We do not have the same concerns regarding the $R \& D$ figures reported by MNCs in Ireland. Indeed, the low corporation tax rate, which limits the value to foreign-owned plants of write offs against $R \& D$ expenditures, reduces the incentive for foreign-owned plants to undertake $R \& D$ expenditures in Ireland, and may itself explain the relatively low rate.

To look at the dispersal of foreign affiliate $R \& D$ spend in Irish manufacturing, we disaggregate by sector. Table 4 compares the national share of R\&D spend (both manufacturing and some non-manufacturing) for 1986 and 1995 (Forfás, 1997). R\&D spend by MNCs is predominantly in the higher technology sectors. In 1986 all foreign plants accounted for 66 per cent of total business expenditure on research and development in Ireland. Of this 66 per cent, two thirds was expended in both of the highertechnology sectors. Again in 1995, the pattern is similar, as real rates of growth were almost identical across all sectors over the period 1986-1995. The OECD, on the basis of a further disaggregation of the Irish high-tech sector into sub-sectors, reports that foreign affiliates were responsible in 1993 for 95 per cent of national R\&D spend in the pharmaceutical sector, 78 per cent in the computer software industry and 64 per cent in the car industry (OECD, 1998:68).

\section{(Table 4)}

\footnotetext{
${ }^{13} R \& D$ intensity is calculated as total R\&D spend of all foreign affiliates divided by the sum of manufacturing turnover produced by all foreign affiliates.

${ }^{14}$ Profit-switching transfer pricing is a mechanism whereby foreign subsidiaries report a higher value of their sales (profits) in Ireland to avail of the low corporation tax rate as discussed in Stewart (1989) and Murphy (1998).
} 
We use plant-level data to summarise the incidence and intensity of R\&D activity in foreign affiliates in Ireland. Tables 5 and 6 show the percentage of the population of foreign-owned plants with ten or more employees undertaking R\&D in 1986 and 1993, the latest year for which the data are available.

\section{(Table 5)}

Table 5 takes the population of 691 foreign-owned plants with ten or more employees in 1986. Approximately 14 per cent of these plants engaged in a minimum amount of $R \& D$ spend in 1986 in the Irish manufacturing sector. ${ }^{15}$ The mean $R \& D$ spend per plant was $£ 400,000$ and the mean number of R\&D personnel employed in R\&D was 13 persons per plant. ${ }^{16}$ Of the total population of foreign-owned plants, less than ten per cent had a formal $R \& D$ department. Using a subset of the population of $R \& D$ spending plants for which sales information is available, we calculated that the mean intensity ( $R \& D$ Spend / Sales) of the foreign-owned R\&D-active plants was 4 per cent. This estimate of $R \& D$ intensity for R\&D-active foreign-owned plants is significantly higher than the aggregate OECD estimate (which covers all plants) of 1.17 per cent (Table 3 ).

It is possible to disaggregate further these totals by nationality of ownership. We divide our population of plants on the basis of whether their parent plant is located in Europe, North America or Asia-Pacific. ${ }^{17}$ The European plants comprise the largest single group of foreign-owned plants in the Irish manufacturing sector. However, only 10 per cent of these plants conducted R\&D in 1986 compared with almost 20 per cent in

\footnotetext{
${ }^{15}$ This is at least $£ 25,000$ Irish punts (the salary for one researcher).

${ }^{16}$ This is not Full Time Equivalents. This is the number of people who have some involvement in R\&D activities without accounting for the time with which they are involved.

${ }^{17}$ We define Asia-Pacific as a term summarising plants from Australia and Asia.
} 
the other two categories. In terms of mean $R \& D$ spend and $R \& D$ intensity (R\&D spend as a percentage of sales) per plant, the North American plants had a mean equal to three times that of the Asian-Pacific owned plants and over twice that of the European contingent. Correspondingly the North American plants had the highest mean number of $R \& D$ persons per plant. Using this plant level analysis, North American plants appear to be the most R\&D-active of all foreign-owned plants. ${ }^{18}$

\section{(Table 6)}

Table 6 shows the equivalent data for 1993. In 1993, the number of plants with ten or more employees was slightly lower at 686 plants, while the percentage of those plants doing a minimum level of R\&D increased to over 24 per cent. The mean R\&D spend per plant is $£ 590,000$ Irish pounds, a real increase of 47.5 per cent over the equivalent 1986 value. The mean number of $R \& D$ personnel in these plants increased fourfold from a mean of 13 persons in 1986 to 62 persons in $1993 .{ }^{19}$ Overall the percentage of plants with a formal $R \& D$ department increased to approximately 15 per cent. The mean $R \& D$ intensity is 3.9 per cent, similar to the 4 per cent reported in 1986. In summary, the percentage of foreign-owned plants reporting $R \& D$ expenditure and the scale of that expenditure has increased over the period.

Similar to the situation outlined in 1986, there are significant differences when we distinguish plants by their nationality of ownership.

\footnotetext{
${ }^{18}$ US R\&D investment in Irish subsidiaries accounts for 5.6\% of all US R\&D investment in Europe. The equivalent share of manufacturing turnover is $2.4 \%$. Calculating R\&D investment as a percentage of turnover, the US plants invest a greater percentage of their turnover in R\&D than in any other European country (2.5\%). The second highest plants are those in Germany which invest $2.0 \%$ of their turnover in R\&D. (OECD, 1998:99)

${ }^{19}$ This measures the number of people who have some involvement in R\&D activities without accounting for the time with which they are involved. In other words, it does not measure full time equivalents.
} 
Both categories of non-European plants have a higher average number of plants undertaking $R \& D$ spend. The highest percentage is for North American plants, with almost 30 per cent undertaking some R\&D spend. North American plants also undertake a scale of annual $R \& D$ investment that is four times the level of European and other Non-European plants. They also have the highest R\&D intensity (4.7\%) followed by the European plants (3.2\%). This slight decrease for the North American plants reflects the fact that their scale of $R \& D$ investment has not increased as fast as their sales over this period. The mean $R \& D$ personnel is 80 persons for North American plants, a five-fold increase from 1986. European plants report a lower intensity of (49), equivalent to over a four fold increase in personnel. North American plants are more likely to have a formal R\&D department (18\%) compared with plants from Europe and Asia-Pacific (14\%).

\section{Tangible Contribution of Foreign-owned Plants to the Host Region}

The importance of foreign-owned firms in national $R \& D$ activities reflects at least in part state policy in attracting the subsidiaries of companies operating in highly $R \& D$ intensive and globally fast-growing industries. The policy of supporting plants in high-tech sectors and the desire for $R \& D$ activities in all plants was designed to ensure (i) a deepening of the plant's commitment to Ireland as measured by the lower propensity to exit of $R \& D$-active relative to non-R\&D-active plants and (ii) a higher quantity of high income net jobs created as measured by a higher level of job persistence in $R \& D$-active relative to non-R\&D-active plants. 
Why would an R\&D-active plant have a higher commitment to the host region than a non-R\&D active plant? Essentially much of the investment in $R \& D$ is a sunk cost, to which there are two elements. First, there is the percentage of annual $R \& D$ investments that are undertaken in capital goods, such as specialised buildings and equipment for research purposes. There is a high probability that these items are location specific, so that if a plant withdrew, much of the value of these facilities would be lost. The second element is the employment of R\&D personnel. Although labour is considered to be mobile, a certain percentage of $R \& D$ personnel in a plant will not move with the plant. ${ }^{20}$ In effect, for an R\&D-active plant, there is a cost to exiting from operating in the host region that does not exist for non-R\&D active MNCs.

Why would foreign-owned plants which undertake R\&D in Ireland be expected to create more employment and higher quality employment in Ireland relative to non-R\&D-active MNCs? Companies which are undertaking $\mathrm{R} \& \mathrm{D}$ are for the most part adapting products for export markets. The Forfás survey indicates that, on average, 63 per cent of all $\mathrm{R} \& \mathrm{D}$ spend by MNC plants in Ireland is for experimental development. The quantity of employment in a plant is a function of its output. We assume that the greater the quantity and range of products produced at the plant, the greater the scale of adaptation required of those products for the local markets. Thus plants undertaking experimental R\&D are hypothesised to have higher production levels than a plant which does not, and, by extension, greater employment.

\footnotetext{
${ }^{20}$ de Arcos et al (1997:4) cite a MERIT interview where the manager of a plant concluded that key R\&D personnel would not be willing to move to the US with the firm, thus the firm would not relocate.
} 
There are several reasons why the employment might be of a higher quality. The first reason is simply that R\&D personnel will be employed directly, which will typically not be the case in a non-R\&D-active plant. The second reason is that plants which undertake $R \& D$ in Ireland are hypothesised (confirmed later on) to remain operational in Ireland for longer time periods than plants which do not undertake $R \& D$. Thus there is a higher probability that an individual job that is created today will exist for longer than an equivalent position in a non-R\&D-active plant. Thirdly, plants which undertook $R \& D$ as an input into the innovation process have also invested heavily in other aspects of innovation. Breathnach and Fitzgerald (1994) noted that R\&D expenditures in 1990 amounted to 36 per cent of all expenditure undertaken by foreign-owned plants on innovation. These plants spent a further 3 per cent on patents and licences, 31 per cent on product design, 21 per cent on trial production and 8 per cent on market analysis. Thus plants which engage in $R \& D$ activity seem to engage in these other categories of activity, in order to apply the fruits of their R\&D activities commercially. All of these activities require highlyskilled individuals, the demand for whom would be much greater than in an assembly plant.

\section{Duration of MNC's in Irish manufacturing}

\section{(A) Lifetable Analysis}

The idea underlying the policy of attracting (a) FDI in highertechnology sectors and (b) $R \& D$ spending plants as opposed to non-R\&D spending plants, is the belief that these plants will have a lower propensity to exit the Irish manufacturing sector. Figure 1 shows us the probabilities 
of survival of all MNC's in the Irish manufacturing sector, in the 19801996 period. $^{21}$

\section{(Figure 1)}

The survival function, based on 1,515 MNC's between 1980 and 1996, summarises the survival experiences of foreign-owned plants for each of the four OECD subsectors. This analysis is not based on the total time that the plants existed in Ireland, but rather only on the time that they remained operational during 1980-1996. Our analysis takes account of any plant which at one point reported employing ten persons or more during this period. A plant can have remained operational (survived) for a maximum of seventeen years (1980-1996) or a minimum of one year.

We note the growing gap between sectors the longer the time period we consider. The probability of a plant remaining in operation in Ireland for the full seventeen years is positively related to the level of technological sophistication of the sector in which it operates. From the data underlying Figure 1, we can derive Table A1 (in the appendix) which shows the estimated probabilities that a plant in a given sector will survive 5, 10 or 17 years over the period 1980-1996. The longer the time period considered ex ante, the lower the probability of the plant remaining operational (surviving) in Ireland for one additional year (Audretsch 1991,1995; Kearns and Ruane, 1998). The probability of all foreignowned plants surviving 17 years in the Irish manufacturing sector is approximately 47 per cent, compared with 55 and 70 per cent probability respectively for five and ten years between 1980 and 1996.

\footnotetext{
${ }^{21}$ These probabilities have been estimated using lifetable analysis. Lifetable analysis is a technique which permits the estimation of the probability of an event (exit) occurring at different time (years) points. It allows for the fact that not all plants will have exited during the period of observation. Lifetable analysis allows a cohort to be distinguished by one characteristic only and the differing probabilities to be estimated for each group.
} 
An equivalent analysis can be undertaken on a cohort of MNC's classified as non-R\&D spending plants or as $R \& D$ spending plants, but only for shorter time horizon of 1986-1996, because of the shorter duration which our $R \& D$ data cover relative to the employment data in the previous lifetable analysis.

\section{(Figures 2(A) and 2(B))}

Taking a cohort of plants (ten or more employees in 1986) it is possible to examine whether the average annual $\mathrm{R} \& \mathrm{D}$ spend of a foreign-owned plant had any bearing on the probability that the plant remained operational (survived) in Ireland over the period 1986-1996. Figure 2(A) illustrates the two survival functions graphically, for R\&D-spending subsidiaries and non-R\&D spending subsidiary plants, respectively. Those foreign-owned plants which engage in $R \& D$ spend have a greater probability of remaining in Ireland for a given time period than non- $R \& D$ spending plants. The probability of a non-R\&D-active MNC remaining ten years is over 60 per cent (Table A2) relative to an equivalent probability of almost 90 per cent for $R \& D$ spending plants. When we make a distinction within $R \& D$ spending plants according to the scale of R\&D spend (Figure 2(B)), we find that the probability of a plant remaining in Ireland for a given time period increases with the scale of R\&D activity. In Table A2 we see that the probability of a large $R \& D$ spender remaining in Ireland for ten years is over ninety per cent relative to eighty five per cent for a small $R \& D$ spender and relative to sixty one per cent for a non-R\&D spending MNC. 


\section{(B) A Cox Duration Model}

A limitation of the lifetable analysis above is the inability to distinguish plants by more than one characteristic, in particular, we were unable to distinguish the R\&D-spending plants by other characteristics, such as plant size and age. The Cox duration model (1972, 1975) estimates the risk of exit (hazard) facing a plant in our cohort as a function of plant and sectoral explanatory variables. This proportional hazards model takes account of duration heterogeneity, i.e., the differing lengths of time over which our plants remained operational post-1986. The hazard is the conditional probability of a plant leaving the manufacturing sector at duration $t$. The hazard rate is the rate at which a plant exits during period $t$ given that it has survived until time $t$, i.e., it measures the risk of exit for a plant during the next year. We obtain a baseline hazard function, $h_{0}(t)$, which is estimated when all of the explanatory variables (covariates) are set at zero. It is an estimate of the risk of exit facing each plant in the cohort in each year 1986-1996. The Cox model then estimates the influence of each of our explanatory variables on this baseline hazard function. Is the hazard of a plant exiting at a moment in time increased or decreased when an explanatory variable is nonzero? A negative (positive) coefficient indicates that this baseline risk of exit at a moment in time is reduced (increased).

In order to use the proportional hazards Cox model, we must assume that the ratio of the baseline hazard function $h_{0}(t)$ and the estimated hazard function $h(t)$ (when an explanatory variable is included) is proportional across time. This implies the contribution of the explanatory variable to the risk of exit across time is identical. In our case, the 
contribution of $R \& D$ activity to the risk of exit facing a plant is the same in 1986 as it is in 1996. The assumption of using this proportional hazards model is that none of our explanatory variables vary across time. They are all cross-sectional.

We express the model to evaluate many independent variables as

$$
h(t)=\left[h_{0}(t)\right] e^{\left(\beta_{1} X_{1}+\beta_{2} X_{2}+\ldots+\beta_{N} X_{n}\right)}
$$

where $h_{0}(t)$ is the baseline hazard function when all of the covariates are set to zero and $h(t)$ is the estimated hazard function when the value of the covariates $\left(x_{1}, x_{2} \ldots x_{n}\right)$ are nonzero.

The emphasis of this paper is on the probability of survival for an foreignowned plant given its characteristics and external environment. The survival function $\mathrm{S}(\mathrm{t})$ is an estimate of the probability of surviving longer than a specified period. The cumulative hazard function $H(t)$ is related to the survival function: $H(t)=-\ln S(t)$, where

$$
S_{t}=\left[S_{0}(t)\right]^{p}
$$

and where $p=e^{\beta x}$. The survival function is obtained by raising the baseline survival function (this is the function when all the explanatory variables are set to zero) to the power of $e^{\beta x}$. The cumulative hazard and the cumulative survival functions approximately add to one, the difference 
from one being due to the standard error of the cumulative survival estimates. Therefore the probability of surviving a given time period is one minus the probability of exiting in that period.

The Cox model is estimated for the population of foreign-owned plants with ten or more employees in 1986. The dependent variable is the length of duration the plant remained operational (survived) post-1986. We include dummy variables to account for each plant's scale of R\&D activity over the period 1986-1993, its nationality, the period in which the plant began operating in Ireland, and the sector in which the plant is operating. In addition we include the mean annual entry rate of foreign-owned plants by industrial subsector and the employment size of the plant in 1986. For a general discussion of the factors affecting survival of plants, see Audretsch (1995) and Siegfried and Evans (1994). Specifically for Ireland, see Walsh et al (1997) for the effect of exchange rates on foreign plants and Kearns and Ruane (1998) for the role of research and development as it affects the survival rates of indigenous plants.

\section{(Table 7)}

\section{Interpretation of the Results}

The estimated model (Table 7) for all plants with ten or more employees in 1986 is statistically significant. ${ }^{22}$ We report the hazard ratio for each of our explanatory variables. A ratio of less (greater) than one confirms that for a one unit increase in a variable, the risk of exit for the plant is reduced (increased). The larger the firm is in 1986, the lower the risk of exit and the higher the probability of survival facing the plant over the period 1986-1996. Plants in the low-tech sectors have a significantly

\footnotetext{
${ }^{22}$ A table of descriptive statistics and correlation coefficients for all exogenous variables are in appendix A in Tables A3 and A4.
} 
lower probability of remaining in Ireland over the period relative to plants in the high-tech sector. The greater the extent of entry of foreign subsidiaries into the Irish manufacturing sector lowers the probability of existing foreign affiliates remaining operational in Ireland. This is contrary to our initial expectations that the continuous entry of high-tech plants would encourage existing plants to remain and avail of spillovers from new plants. One possible explanation for our estimate may lie in the observation that the industrial restructuring which has taken place on a global scale may be being replicated within Ireland. Those firms that are currently expanding within an industry will be expanding their FDI while simultaneously their declining competitors will be contracting their FDI. ${ }^{23}$ Plants engaging in both small and large scale $R \& D$ investments have a higher probability of remaining in Ireland relative to non-R\&D spending plants.

Equations 2 through 7 provide alternative measurements of a plant's technological activity. Using these alternative measures we attempt to account not only for the presence of R\&D activity but for the scale of activity within a plant. In Equation 2 we observe that large R\&D spending plants have a smaller risk of exit relative to both small and non-R\&D spending plants. All six measures of the scale of $R \& D$ activity are significant and all reduce the risk of exit facing a plant, ceteris paribus.

\footnotetext{
${ }^{23}$ Two well known examples in Ireland would be the major expansions of Intel and IBM while simultaneously Verbatim and Seagate were withdrawing from Ireland.
} 


\section{The Quantity and Quality of Employment Created}

The second motive behind government policy towards expanding $\mathrm{R} \& \mathrm{D}$-active plants derives from the belief that such plants would create a greater quantity and quality of employment than similar non-R\&D-active plants.

\section{(A) The Quantity of Employment Created}

The following tables are based on an analysis of a cohort (foreign affiliates with ten or more employees in 1986). Overall there is net job destruction in the cohort (11.1\%) over the period 1986-1996. However within sectors in Table 8, there is net job creation by MNC plants in the two higher tech sectors $(3.1 \%$ and $2.4 \%)$ in comparison with the net job destruction in plants in the two lower tech sectors (-10.4\% and $-28.8 \%)$.

\section{(Table 8)}

It is also possible to analyse how the overall net job destruction rate of the cohort varies according to whether the plant is or is not an R\&Dspending plant as in Table 9. Large $R \& D$ spenders have a net job creation rate of over 12 per cent compared to the net job destruction rate of over 28 per cent for both small $R \& D$ spending and non-R\&D spending plants. $R \& D$ spend is not associated with significant net job creation unless undertaken on a significant scale.

\section{(Table 9)}

An extension of the previous analysis is to consider those foreign affiliates in the cohort which are alive in both 1986 and 1996. There are 496 such plants out of a total of 691 . This allows us to distinguish the 
effects of closures on the data. When we remove the plants which have exited, we find that there is overall net job creation rate of 9.6 per cent. There is a 20 per cent net job creation rate for large R\&D spending plants, compared with under 12 per cent for non-R\&D spending plants. Small $\mathrm{R} \& \mathrm{D}$-spending plants have a net job destruction rate of 20 per cent (see Table 10).

\section{(Table 10)}

\section{(B) The Quality of Employment Created}

We can attempt to measure the quality of employment created using measures of job persistence (Davis and Haltiwanger 1996: 21-26). We define quality in terms of the duration that a new job will exist, since our data do not allow us to account for quality in terms of the skilled or unskilled nature of the employment. Essentially whenever a quantity of jobs is created, we estimate the percentage of those jobs that still exist in $1,2,3$ or 4 years time. A limitation of this analysis is that we cannot be sure that they are precisely the same jobs that survive over a given time period. We are limited to examining to what extent the company maintains its new employment levels which contain the newly created jobs. If all of the jobs created survive, we note that there is a 100 per cent job persistence rate. If the plants employment level falls to a level below that which existed before the jobs were created, we say that there is zero per cent persistence rate.

Table 11 is based upon a cohort analysis of all plants with ten or more employees in 1986. Overall the average persistence of jobs created is high. After four years almost 95 per cent of jobs persist or survive when the category considered is all plants. However, when we look at plants disaggregated by the sector in which they operate, we note that the 
persistence rates of jobs created in both the high-tech sectors $193.8 \%$ and $97.5 \%$ ) are relatively higher than the job persistence rates in the lower tech sectors $(54.7 \%$ and $63.2 \%) .{ }^{24}$ This pattern can be observed whether we discuss the one, two or three year persistence rates.

\section{(Table 11)}

When we consider $R \& D$ spenders in Table 12, the average persistence rate of jobs created is higher in the majority (although not the case for one year rate) for both the large and small R\&D spenders relative to the non-R\&D spenders. The persistence rate for the non-R\&D spending plants falls off sharply by the second year and by the fourth year (43.7\%) is under half that of the equivalent rate for jobs created by large $R \& D$ spending plants $(99.0 \%)$.

(Table 12)

\section{SUMMARY and CONCLUSIONS}

In this paper we have examined whether the R\&D activities of MNCs in Ireland have any bearing on their contribution to Ireland's economic development. Allowing for plant and sectoral characteristics, we compared the survival experiences and the employment performance of R\&D-active MNCs, relative to non-R\&D active MNCs. We found that plant survival was positively related to size, the level of sophistication of the sector of activity, and the plant's being R\&D-active. A cohort analysis of employment at plant level indicated that job losses were greater and job persistence lower in the low-tech sectors and among non-R\&D spenders compared with $R \& D$ spenders.

\footnotetext{
${ }^{24}$ Care should be taken in interpreting the overall four year persistence rate for all plants as an average of the above four sectors. In this case the majority weighting determined by the number of jobs created and the stock of employment in each category is predominantly on the higher-tech sectors.
} 
Those MNCs locating R\&D activities in their Irish subsidiaries are predominantly large North American plants operating in the high tech sectors. Thus our analysis confirms a positive association between this $\mathrm{R} \& \mathrm{D}$ activity and a tangible contribution of MNCs to Ireland, through plant survival and job persistence. Although it has long been recognised that the attraction of FDI to Ireland has been beneficial, the results of this paper supports the idea that R\&D-active firms generally provide greater benefit to the economy. On employment grounds alone, policy should favour R\&D-active plants in high-tech sectors.

Differences between our plant level results and those aggregate estimates provided at OECD level point to the importance of plant level studies in assessing the impact of all R\&D activities on economies. Plant level data allow one to distinguish between the proportion of $R \& D$-active firms in a particular group and the scale of the $R \& D$ activity in which they engage. Aggregate statistics can hide the importance of the R\&D impact, if account is not taken of differences in the proportion of firms undertaking $R \& D$ in a sector. In the Irish case, the level of $R \& D$ intensity of foreignowned firms at sectoral level is significantly lower than the intensity at plant level because of the high proportion of non-R\&D-active foreign firms.

To develop this analysis, further study is required of the intangible effects of MNCs' technological activities on their host economies. de Arcos et al (1997) conclude, on the basis of their work, that ' $[t]$ he results indicate that FDI holds little promise for peripheral regions as a means of increasing the innovative capacity of the host region, though of course FDI offers benefits in terms of employment - at least over the short to the 
medium term. The most innovative FDI, with the greatest potential for technology spillovers and embeddedness, will not willingly locate in peripheral regions but will be attracted to the core regions of Europe' ( p.128) . This strong conclusion is worthy of consideration in an Irish context. 


\section{TABLES}

Table 1: Growth in Firm numbers and Employment in Foreign-owned Industry in Ireland $1980-1996$

\begin{tabular}{lccccc}
\hline Sector (OECD) & High-Tech & $\begin{array}{c}\text { Medium- } \\
\text { High-tech }\end{array}$ & $\begin{array}{c}\text { Medium-Low- } \\
\text { tech }\end{array}$ & Low-Tech & Total \\
\hline No. of plants 1980 & 68 & 129 & 122 & 153 & 472 \\
No. of plants 1996 & 171 & 210 & 163 & 164 & 708 \\
\% Change & $151.5 \%$ & $62.8 \%$ & $33.6 \%$ & $7.2 \%$ & $50.0 \%$ \\
& & & & & \\
Employment 1980 & 10216 & 18792 & 10953 & 29280 & 69241 \\
Employment 1996 & 27711 & 29160 & 11572 & 23303 & 91746 \\
\% Change & $171.3 \%$ & $55.2 \%$ & $5.7 \%$ & $-20.4 \%$ & $32.5 \%$ \\
\hline
\end{tabular}

Source: Calculated using data from Forfás.

Table 2: Mean Annual Entry Rates 1980-1996

\begin{tabular}{lccccc}
\hline $\begin{array}{l}\text { Sector (OECD) } \\
(\mathbf{1 9 8 0 - 1 9 9 6 )}\end{array}$ & High-Tech & $\begin{array}{c}\text { Medium } \\
\text { High-tech }\end{array}$ & $\begin{array}{c}\text { Medium } \\
\text { Low-tech }\end{array}$ & Low-Tech & Total \\
\hline Mean Annual Entry Rate & $7.2 \%$ & $4.2 \%$ & $3.6 \%$ & $4.0 \%$ & $4.6 \%$ \\
\hline
\end{tabular}

Source: Calculated using data from Forfás.

\begin{tabular}{l} 
Table 3: OECD Estimates of the Share of National R\&D accounted \\
for by Foreign Affiliates and the R\&D Intensity of that activity. \\
\hline Country \\
$\begin{array}{cccc}\text { \% Share of Total } & \text { Intensity of } & \text { \% Share of Total } \\
\text { National Industrial } & R \& D \text { Activity of } & \text { Manufacturing } \\
\text { R\&D by Foreign } & \text { Foreign } & \text { Turnover by }\end{array}$
\end{tabular}

Affiliates Affiliates $c$ Foreign Affiliates

\begin{tabular}{lccc}
\hline Ireland (1993) & $\mathbf{6 8 \%}$ & $\mathbf{1 . 1 7 \% ( 6 ) a}$ & $\mathbf{5 4 . 0 ( 1 )} b$ \\
United Kingdom (1995) & $37 \%$ & $2.09 \%(4)$ & $31.0 \%(3)$ \\
Spain (1995) & $33 \%$ & $N A$ & $N A$ \\
Sweden (1995) & $21 \%$ & $2.39 \%(3)$ & $18.7 \%(6)$ \\
Netherlands (1993) & $17 \%$ & $0.76 \%(7)$ & $42.4 \%(2)$ \\
Turkey & $16.5 \%$ & $N A$ & $N A$ \\
France (1994) & $16 \%$ & $1.78 \%(5)$ & $21.0 \%(5) b$ \\
Germany (1993) & $16 \%$ & $3.17 \%(1)$ & $28.1 \%(4)$ \\
Greece (1993) & $10 \%$ & $N A$ & $N A$ \\
Finland (1993) & $8 \%$ & $2.61 \%(2)$ & $7.59 \%(7)$ \\
\hline
\end{tabular}

Source: OECD (1998) Page 4-5 \& graphically illustrated Page 20. a=own estimate $b=1990$ figure. $\mathrm{c}=$ calculated as (R\&D Spend / Turnover). Ranking relative to column one provided in ( )s.

\footnotetext{
${ }^{25}$ This table is based on the population of Foreign-owned manufacturing companies with ten or more employees in 1980 and 1996.

${ }^{26}$ These estimates include R\&D undertaken by foreign affiliates in some non-manufacturing industries.
} 


\begin{tabular}{|c|c|c|c|}
\hline $\begin{array}{l}\text { Foreign-Owned } \\
\text { Sector }\end{array}$ & $\begin{array}{c}1986 \\
\text { \% Share of Total } \\
\text { BERD }\end{array}$ & $\begin{array}{c}1995 \\
\text { \% Share of Total } \\
\text { BERD }\end{array}$ & $\begin{array}{c}\text { Per Annum Real } \\
\text { Rate of Growth } \\
\% \\
\end{array}$ \\
\hline High-tech & $31 \%$ & $29 \%$ & $14 \%$ \\
\hline Medium-high-tech & $14 \%$ & $13 \%$ & $14 \%$ \\
\hline Medium-Low-tech & $3 \%$ & $2 \%$ & $13 \%$ \\
\hline Low-tech & $6 \%$ & $6 \%$ & $15 \%$ \\
\hline Non-Manufacturing & $12 \%$ & $14 \%$ & $17 \%$ \\
\hline All Foreign Plants & $66 \%$ & $64 \%$ & $15 \%$ \\
\hline All Indigenous Plants & $34 \%$ & $36 \%$ & $16 \%$ \\
\hline $\begin{array}{c}\text { All Manufacturing } \\
\text { Plants }\end{array}$ & $100 \%$ & $100 \%$ & $15 \%$ \\
\hline
\end{tabular}

Source: Forfás (1997)

Table 5: R\&D Activities by Nationality of Ownership (1986)

\begin{tabular}{|c|c|c|c|c|}
\hline Nationality of Ownership & European & $\begin{array}{l}\text { USA \& } \\
\text { Canada }\end{array}$ & Asia-Pacific & Total \\
\hline Popn. Foreign Plants 1986 & 402 & 263 & 26 & 691 \\
\hline Number of R\&D Spenders & 41 & 50 & 5 & 96 \\
\hline $\begin{array}{l}\text { \% } 1986 \text { Cohort who are } \\
\text { R\&D Spenders }\end{array}$ & $10.20 \%$ & $19.01 \%$ & $19.23 \%$ & $13.89 \%$ \\
\hline $\begin{array}{l}\text { Mean R\&D Spend per } \\
\text { plant }\end{array}$ & 219 & 573 & 142 & 400 \\
\hline Average R\&D Intensity - & $2.1 \%$ & $6.0 \%$ & $0.9 \%$ & $4.0 \%$ \\
\hline R\&D 1986 / Sales 1986 a & $(34)$ & $(37)$ & $(4)$ & $(75)$ \\
\hline $\begin{array}{l}\text { Mean R\&D Personnel of } \\
\text { each R\&D plant }\end{array}$ & 11 & 16 & 8 & 13 \\
\hline $\begin{array}{l}\% \quad 1986 \text { Cohort with } \\
\text { formal R\&D department }\end{array}$ & $7.46 \%$ & $11.40 \%$ & $15.38 \%$ & $9.26 \%$ \\
\hline
\end{tabular}


Table 6: R\&D Activities by Nationality of Ownership (1993)

\begin{tabular}{|c|c|c|c|c|}
\hline Nationality of Ownership & European & $\begin{array}{l}\text { USA \& } \\
\text { Canada }\end{array}$ & Asia-Pacific & Total \\
\hline Popn. Foreign Firms 1993 & 373 & 277 & 36 & 686 \\
\hline Number of R\&D Spenders & 75 & 81 & 9 & 165 \\
\hline $\begin{array}{l}\% 1993 \text { Cohort who are } \\
\text { R\&D Spenders }\end{array}$ & $20.11 \%$ & $29.24 \%$ & $25.00 \%$ & $24.05 \%$ \\
\hline $\begin{array}{l}\text { Mean R\&D Spend per } \\
\text { plant b }\end{array}$ & 213 & 978 & 226 & 590 \\
\hline Average $R \& D$ Intensity - & $3.2 \%$ & $4.7 \%$ & $1.1 \%$ & $3.9 \%$ \\
\hline R\&D 1993 / Sales 1993 a & (64) & (74) & (7) & (145) \\
\hline $\begin{array}{l}\text { Mean R\&D Personnel of } \\
\text { each R\&D plant }\end{array}$ & 49 & 80 & 15 & 62 \\
\hline $\begin{array}{l}\% 1993 \text { Cohort with } \\
\text { formal R\&D department }\end{array}$ & $12.87 \%$ & $17.69 \%$ & $13.89 \%$ & $14.87 \%$ \\
\hline
\end{tabular}


Table 7: Results of the Cox Duration Model

\begin{tabular}{|c|c|c|c|c|c|c|c|}
\hline \multirow[t]{2}{*}{ Variable } & \multicolumn{6}{|c|}{ Hazard Ratio } & \multirow[b]{2}{*}{ Eqn 7} \\
\hline & Eqn 1 & Eqn 2 & Eqn 3 & Eqn 4 & Eqn 5 & Eqn 6 & \\
\hline $\begin{array}{l}\text { Firm Size in } 1986 \\
\text { Plant Nationality: }\end{array}$ & $.998 * *$ & 0.999* & $.998 * * *$ & $.998 * * *$ & $.998 * * *$ & $.998 * *$ & $.997 * * *$ \\
\hline $\begin{array}{l}\text { European } \\
\text { Nationality }\end{array}$ & - & - & - & - & - & - & - \\
\hline North American & .896 & 0.897 & .909 & .917 & .898 & .920 & .869 \\
\hline $\begin{array}{l}\text { Other Non-European } \\
\text { Sector: }\end{array}$ & .655 & 0.647 & .665 & .791 & .689 & .636 & .685 \\
\hline High-tech & - & - & - & - & - & - & - \\
\hline Medium-High-tech & 1.444 & 1.428 & 1.469 & 1.371 & $1.695 *$ & 1.290 & 1.582 \\
\hline Medium-Low-tech & 1.437 & 1.390 & 1.610 & 1.450 & $1.876 * *$ & 1.344 & $1.745 * *$ \\
\hline Low-Tech & $2.565 * * *$ & $2.474 * * *$ & $3.073 * * *$ & $2.846 * * *$ & $3.098 * * *$ & $2.662 * * *$ & $3.335 * * *$ \\
\hline Started in Ireland: & & & & & & & \\
\hline Pre 1973 & - & - & - & - & - & - & - \\
\hline 1973-1982 & 0.963 & 0.971 & 0.961 & 0.986 & 1.015 & 0.985 & .963 \\
\hline Post 1982 & 1.006 & 1.021 & 0.995 & 1.035 & 1.045 & 1.065 & .986 \\
\hline $\begin{array}{l}\text { Annual MNC Entry } \\
\text { R\&D Activity: } \\
\text { 1. Non-R\&D }\end{array}$ & $1.132 * * *$ & $1.133 * * *$ & $1.149 * * *$ & $1.124 * * *$ & $1.178 * * *$ & $1.118 * * *$ & $1.151 * * *$ \\
\hline Spender & & & & & & & \\
\hline All R\&D Spenders & $.288 * * *$ & & & & & & \\
\hline 2. Small R\&D & & $0.381 * * *$ & & & & & \\
\hline Spender & & & & & & & \\
\hline Large R\&D Spender & & $0.215 * * *$ & & & & & \\
\hline 3. Average Annual & & & $0.999 * *$ & & & & \\
\hline R\&D Investment & & & & & & & \\
\hline 4. Existence of a & & & & $0.304 * * *$ & & & \\
\hline formal R\&D & & & & & & & \\
\hline Department & & & & & & & \\
\hline 5. $\%$ Sales of & & & & & $.974 * * *$ & & \\
\hline Innovative products & & & & & & & \\
\hline 6. Average Annual & & & & & & $.883 * * *$ & \\
\hline R\&D Personnel & & & & & & & \\
\hline 7. Average R\&D & & & & & & & $.922 * *$ \\
\hline Intensity (R\&D / & & & & & & & \\
\hline Sales) & & & & & & & \\
\hline Log Likelihood & -1196.38 & -1195.25 & -1213.81 & -1204.54 & -1198.19 & -1200.83 & -1215.71 \\
\hline Chi Square (11) & 103.04 & 105.31 & 68.18 & 86.72 & 99.43 & 94.14 & 64.39 \\
\hline Prob > Chi2 & 0.0000 & 0.0000 & 0.0000 & 0.0000 & 0.0000 & 0.0000 & 0.0000 \\
\hline$N$ & 691 & 691 & 691 & 691 & 691 & 691 & 691 \\
\hline Time at risk & 6355 & 6355 & 6355 & 6355 & 6355 & 6355 & 6355 \\
\hline
\end{tabular}

Source: Calculated using data from Forfás. Categorical Variables are benchmarked against the category. ${ }^{* * *}=$ significant at the $1 \%$ level ${ }^{* *}=$ significant at the $5 \%$ level $*=$ significant at the $10 \%$ level 
Table 8: Net job change by Sector: A Cohort Analysis

\begin{tabular}{cccccc}
\hline Category & $\begin{array}{c}\text { Stock of } \\
\text { Employ. '86 }\end{array}$ & $\begin{array}{c}\text { Gross Jobs } \\
\text { Created }\end{array}$ & $\begin{array}{c}\text { Gross Jobs } \\
\text { Destroyed }\end{array}$ & $\begin{array}{c}\text { Stock of } \\
\text { Employ. '96 }\end{array}$ & $\begin{array}{c}\text { \% Jobs Change } \\
1986-1996\end{array}$ \\
\hline High-tech & 14,593 & 5,926 & $(5,470)$ & 15,049 & $3.1 \%$ \\
$\begin{array}{c}\text { Medium- } \\
\text { High-tech }\end{array}$ & 22,884 & 7,796 & $(7,245)$ & 23,435 & $2.4 \%$ \\
$\begin{array}{c}\text { Medium- } \\
\text { Low-tech }\end{array}$ & 11,087 & 2,210 & $(3,357)$ & 9,940 & $(10.4 \%)$ \\
Low-tech & 29,891 & 5,980 & $(14,584)$ & 21,287 & $(28.8 \%)$ \\
All Plants & 78,455 & 21,912 & $(30,656)$ & 69,711 & $(11.1 \%)$ \\
\hline
\end{tabular}

Source: Calculated using data from Forfás.

Table 9: Net job change by R\&D Activity: A Cohort Analysis

\begin{tabular}{cccccc}
\hline Category & $\begin{array}{c}\text { Stock of } \\
\text { Employ. '86 }\end{array}$ & $\begin{array}{c}\text { Gross Jobs } \\
\text { Created }\end{array}$ & $\begin{array}{c}\text { Gross Jobs } \\
\text { Destroyed }\end{array}$ & $\begin{array}{c}\text { Stock of } \\
\text { Employ. '96 }\end{array}$ & $\begin{array}{c}\text { \% Jobs Change } \\
1986-1996\end{array}$ \\
\hline $\begin{array}{c}\text { Non-R\&D } \\
\quad 3 p e n d e r\end{array}$ & 34,854 & 6,854 & $(19,912)$ & 24,796 & $(28.2 \%)$ \\
$\begin{array}{c}\text { Small R\&D } \\
\text { Spender }\end{array}$ & 9,874 & 1,360 & $(4,144)$ & 7,090 & $(28.2 \%)$ \\
$\begin{array}{c}\text { Large R\&D } \\
\text { Spender } \\
\text { Total }\end{array}$ & 33,727 & 13,698 & $(9,600)$ & 37,825 & $12.2 \%$ \\
\hline
\end{tabular}

Source: Calculated using data from Forfás.

Table 10: Net job change by R\&D Activity: A Cohort (Survivors)

Analysis

\begin{tabular}{cccccc}
\hline Category & $\begin{array}{c}\text { Stock of } \\
\text { Employ. '86 }\end{array}$ & $\begin{array}{c}\text { Gross Jobs } \\
\text { Created }\end{array}$ & $\begin{array}{c}\text { Gross Jobs } \\
\text { Destroyed }\end{array}$ & $\begin{array}{c}\text { Stock of } \\
\text { Employ. '96 }\end{array}$ & $\begin{array}{c}\text { \% Jobs Change } \\
1986-1996\end{array}$ \\
\hline $\begin{array}{c}\text { Non-R\&D } \\
\text { Spender }\end{array}$ & 22,205 & 6,854 & $(4,263)$ & 24,796 & $11.7 \%$ \\
$\begin{array}{c}\text { Small R\&D } \\
\text { Spender }\end{array}$ & 8,870 & 1,360 & $(3,140)$ & 7,090 & $(20.0 \%)$ \\
$\begin{array}{c}\text { Large R\&D } \\
\text { Spender }\end{array}$ & 31,557 & 13,698 & $(7,430)$ & 37,825 & $19.9 \%$ \\
$\quad$ Total & 62,632 & 21,912 & $(14,833)$ & 69,711 & $9.6 \%$ \\
\hline
\end{tabular}

Source: Calculated using data from Forfás. 
Table 11: Job Creation Persistence Rates by Sector

\begin{tabular}{|c|c|c|c|c|}
\hline Category & $\begin{array}{l}\text { Average } 1 \text { year } \\
\text { persistence } \\
\text { Jobs Created }\end{array}$ & $\begin{array}{l}\text { Average } 2 \text { Year } \\
\text { Persistence } \\
\text { Jobs Created }\end{array}$ & $\begin{array}{c}\text { Average } 3 \text { Year } \\
\text { Persistence } \\
\text { Jobs Created }\end{array}$ & $\begin{array}{l}\text { Average } 4 \text { Year } \\
\text { Persistence } \\
\text { Jobs Created }\end{array}$ \\
\hline High-Tech & $99.57 \%$ & $99.57 \%$ & $94.58 \%$ & $93.81 \%$ \\
\hline $\begin{array}{l}\text { Medium- } \\
\text { Hiah-tech }\end{array}$ & $99.41 \%$ & $99.35 \%$ & $97.80 \%$ & $97.48 \%$ \\
\hline $\begin{array}{l}\text { Medium- } \\
\text { Low-tech }\end{array}$ & $88.47 \%$ & $78.82 \%$ & $70.45 \%$ & $54.67 \%$ \\
\hline Low-tech & $87.00 \%$ & $77.69 \%$ & $63.22 \%$ & $63.22 \%$ \\
\hline All Plants & $99.04 \%$ & $97.60 \%$ & $94.70 \%$ & $93.95 \%$ \\
\hline
\end{tabular}

Source: Calculated using data from Forfás.

Table 12: Job Creation Persistence Rates by R\&D Activity

\begin{tabular}{lcccc}
\hline Category & $\begin{array}{c}\text { Average 1 year } \\
\text { persistence } \\
\text { Jobs Created }\end{array}$ & $\begin{array}{c}\text { Average 2 Year } \\
\text { Persistence } \\
\text { Jobs Created }\end{array}$ & $\begin{array}{c}\text { Average 3 Year } \\
\text { Persistence } \\
\text { Jobs Created }\end{array}$ & $\begin{array}{c}\text { Average } 4 \text { Year } \\
\text { Persistence } \\
\text { Jobs Created }\end{array}$ \\
\hline $\begin{array}{l}\text { Non-R\&D } \\
\text { spender }\end{array}$ & $99.04 \%$ & $76.65 \%$ & $60.88 \%$ & $43.73 \%$ \\
$\begin{array}{l}\text { Small } \\
\text { R\&D } \\
\text { spender } \\
\text { Large }\end{array}$ & $86.09 \%$ & $84.54 \%$ & $70.72 \%$ & $52.54 \%$ \\
$\begin{array}{l}\text { R\&D } \\
\text { spender }\end{array}$ & $99.08 \%$ & $99.08 \%$ & $99.08 \%$ & $99.08 \%$ \\
All Plants & $99.04 \%$ & $97.60 \%$ & $94.70 \%$ & $93.95 \%$
\end{tabular}

Source: Calculated using data from Forfás. 


\section{FIGURES}

Figure 1: A Survival Function of Foreign-Owned Plants in Ireland 1980-1996 by Sector.

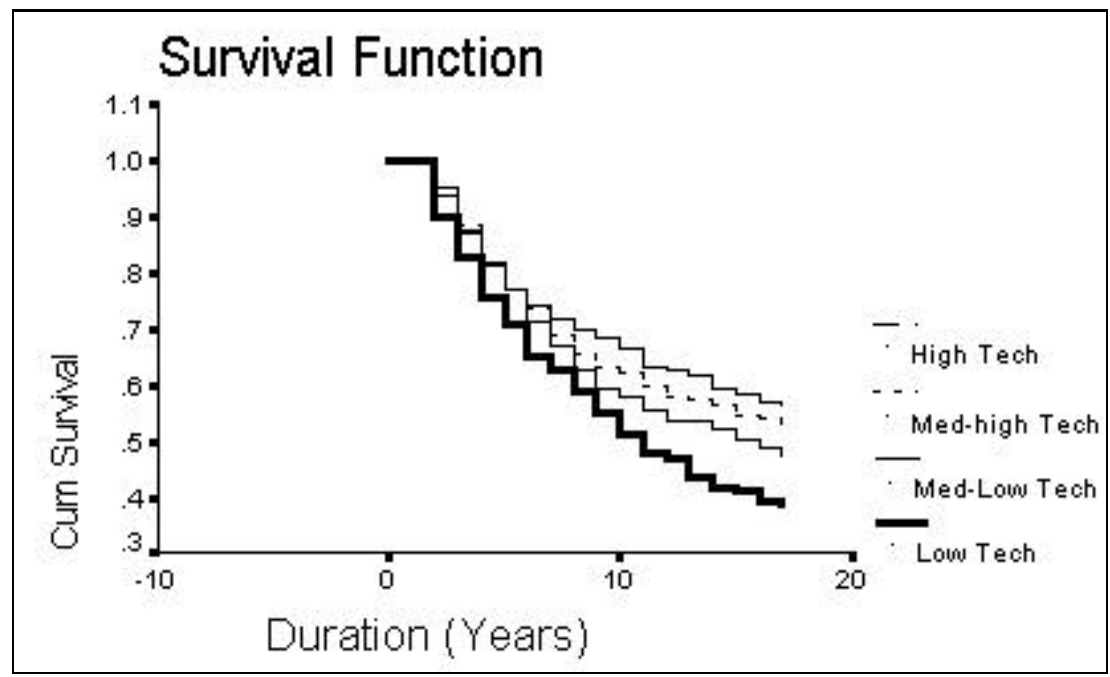

Source: Calculated using data from Forfás.

Figure 2 (A): A Survival function of Foreign-owned Plants in Ireland 1986-1996 by R\&D Activity.

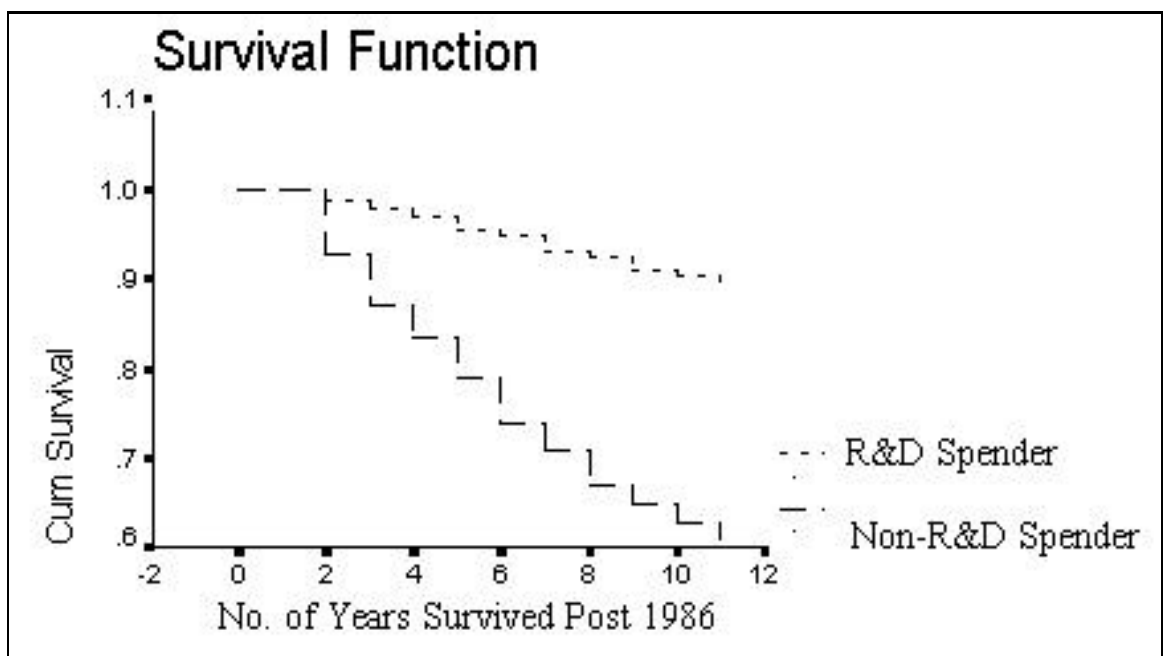

Source: Calculated using data from Forfás. 
Figure 2 (B): A Survival function of Foreign-owned Plants in Ireland 1986-1996 by Scale of R\&D Activity.

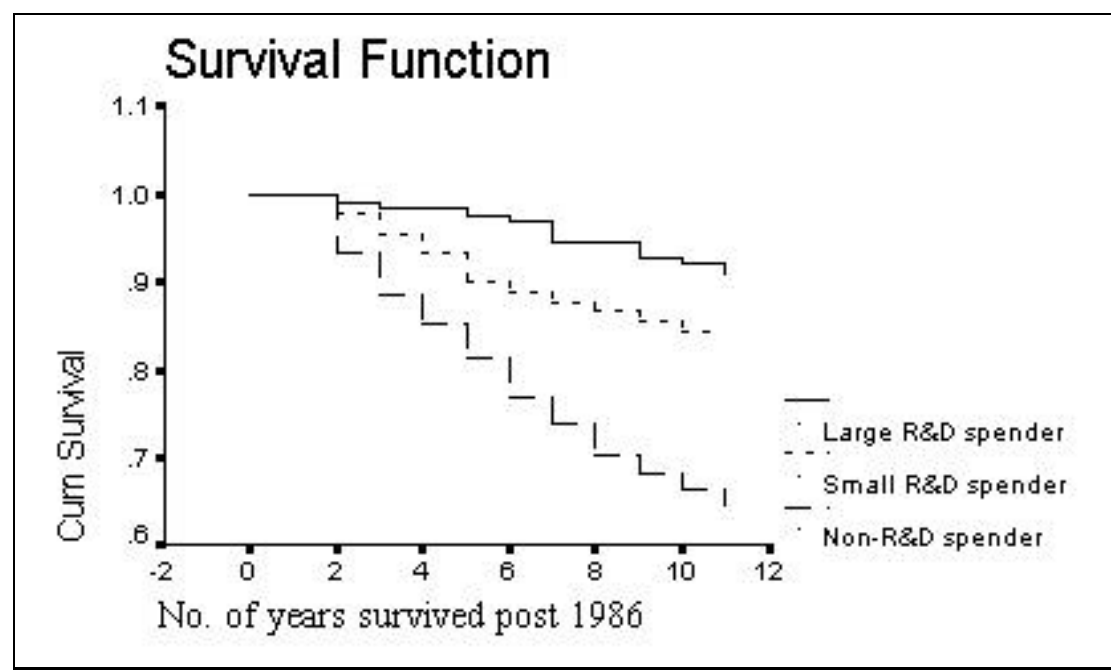

Source: Calculated using data from Forfás.

\section{Appendix A}

Table A1: Lifetable Analysis of Foreign-owned plants by Sector 19801996

\begin{tabular}{|c|c|c|c|c|c|}
\hline $\begin{array}{l}\text { Sector (OECD) } \\
\text { Probability of Staying: }\end{array}$ & $\begin{array}{l}\text { High- } \\
\text { Tech }\end{array}$ & $\begin{array}{l}\text { Medium- } \\
\text { High-tech }\end{array}$ & $\begin{array}{l}\text { Medium- } \\
\text { Low-tech }\end{array}$ & Low-Tech & $\begin{array}{c}\text { All } \\
\text { Plants }\end{array}$ \\
\hline 5 years & $74.52 \%$ & $73.59 \%$ & $71.38 \%$ & $65.32 \%$ & $70.36 \%$ \\
\hline 10 years & $63.47 \%$ & $59.95 \%$ & $55.42 \%$ & $48.07 \%$ & $55.18 \%$ \\
\hline $\begin{array}{l}17 \text { years (1980- } \\
1996)\end{array}$ & $55.97 \%$ & $52.94 \%$ & $46.96 \%$ & $38.89 \%$ & $47.02 \%$ \\
\hline
\end{tabular}

Source: Calculated using data from Forfás.

Table Note A1:Wilcoxon-Gehan statistics show that the difference in probabilities of survival between plants in different sectors are statistically significant at the $1 \%$ level.

Table A2: Lifetable Analysis of Foreign-owned plants by R\&D Activity 1986-1996

\begin{tabular}{lcccc}
\hline $\begin{array}{l}\text { Scale of R\&D spend } \\
\text { Probability of Staying: }\end{array}$ & $\begin{array}{c}\text { non-R\&D } \\
\text { Spenders }\end{array}$ & $\begin{array}{c}\text { Total R\&D } \\
\text { Spenders }\end{array}$ & $\begin{array}{c}\text { Small R\&D } \\
\text { Spenders }\end{array}$ & $\begin{array}{c}\text { Large R\&D } \\
\text { Spenders }\end{array}$ \\
\hline $\mathbf{5}$ years & $76.79 \%$ & $93.55 \%$ & $88.89 \%$ & $96.85 \%$ \\
& & & & \\
$\mathbf{1 0}$ years & $64.35 \%$ & $88.02 \%$ & $84.44 \%$ & $90.55 \%$ \\
\hline
\end{tabular}

Source: Calculated using data from Forfás. 
Table Note A2:Wilcoxon-Gehan statistics show that the difference in probabilities of survival between $R \& D$-active and non- $R \& D$ active plants and between large and small scale $R \& D$ spending plants are statistically significant at the $1 \%$ level.

\section{Table A3: Descriptive Statistics for 691 Foreign-Owned Plants and variables used in Cox Regression}

\begin{tabular}{|c|c|c|c|c|c|}
\hline Variable & Description & Mean & St. Dev & Minimum & Maximum \\
\hline R\&D Scale & $\begin{array}{l}\text { Based on Average Annual } \\
\text { R\&D Spend 1986-1993 }\end{array}$ & & & 0 & 2 \\
\hline Start Period & $\begin{array}{l}\text { Prior to } 1973,1973-1982, \\
\text { Post } 1982\end{array}$ & & & 0 & 2 \\
\hline Sector & $\begin{array}{l}\text { High, Med-High, Med-low or } \\
\text { Low Tech }\end{array}$ & & & 1 & 4 \\
\hline $\begin{array}{l}\text { Entry Rate of } \\
\text { Foreign Plants }\end{array}$ & $\begin{array}{l}\text { Average Annual Entry Rate } \\
\text { of foreign plants 1986-1996 }\end{array}$ & $5.57 \%$ & $2.59 \%$ & $3 \%$ & $14 \%$ \\
\hline $\begin{array}{l}\text { Plant Size in } \\
1986\end{array}$ & $\begin{array}{l}\text { Employment Size of Plant in } \\
1986\end{array}$ & 113.54 & 157.94 & 10 & 1700 \\
\hline Nationality & $\begin{array}{l}\text { North American, European or } \\
\text { Other Non-European }\end{array}$ & & & 0 & 2 \\
\hline $\begin{array}{l}\text { Average Annual } \\
\text { R\&D Investment }\end{array}$ & $\begin{array}{l}\text { Average Annual R\&D based } \\
\text { on survey responses ('000s) }\end{array}$ & 378.30 & 59.79 & 1.83 & 11637.17 \\
\hline $\begin{array}{l}\text { Formal R\&D } \\
\text { Department? }\end{array}$ & $\begin{array}{l}\text { Ever reported a formal } \\
\text { department 1986-1993? }\end{array}$ & & & 0 & 1 \\
\hline $\begin{array}{l}\text { \% Sales of } \\
\text { Innovative Prods }\end{array}$ & $\begin{array}{l}\% \text { of sales from products } \\
\text { developed in last } 3-5 \text { yrs? }\end{array}$ & $35.89 \%$ & $1.60 \%$ & $0 \%$ & $100 \%$ \\
\hline $\begin{array}{l}\text { Average R\&D } \\
\text { Personnel } \\
\end{array}$ & $\begin{array}{l}\text { Average Annual R\&D } \\
\text { Personnel (not FTE) }\end{array}$ & 5.04 & .64 & .00 & 229.5 \\
\hline $\begin{array}{l}\text { Average R\&D } \\
\text { Intensity }\end{array}$ & $\begin{array}{l}\text { Mean Annual R\&D Spend as } \\
\text { a } \% \text { of Sales }\end{array}$ & .03 & .00 & .00 & .65 \\
\hline
\end{tabular}

\section{Table A4: Simple correlation coefficients for exogenous variables in Eqn 1 in Table 7}

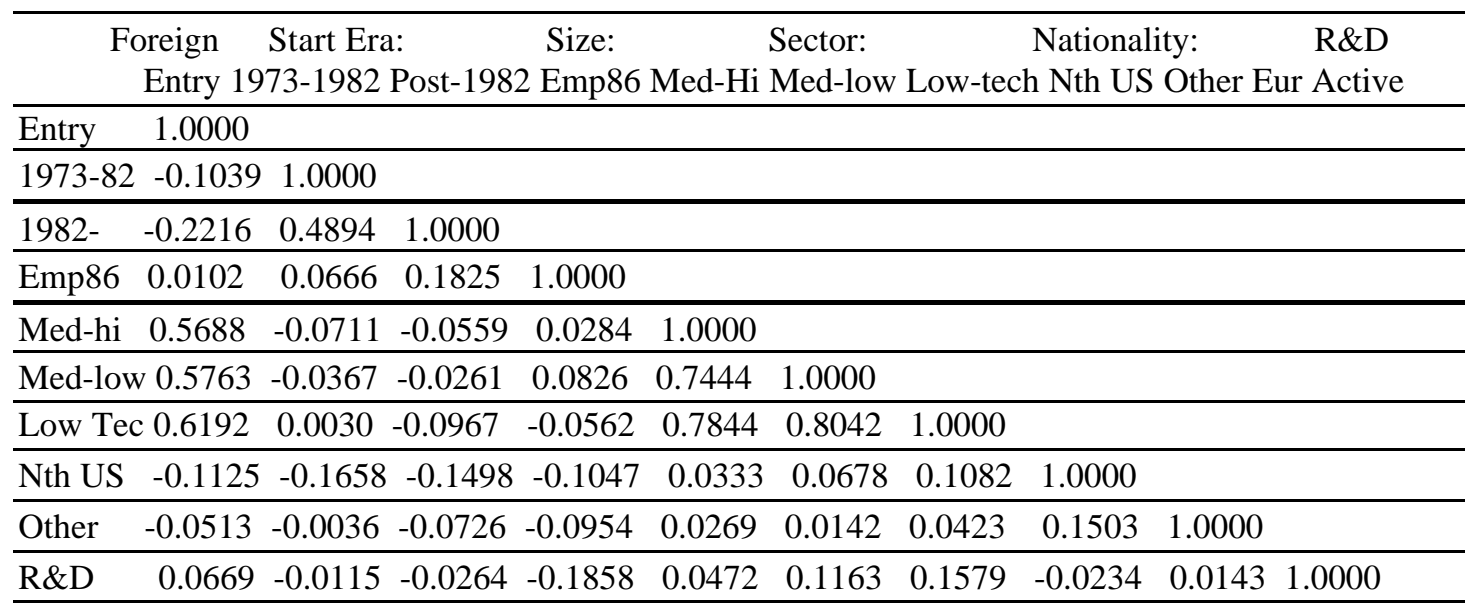




\section{REFERENCES}

Archibugi, D. and J. Michie, (1997), The globalisation of technology: a new taxonomy. In: D. Archibugi and J. Michie (eds) Technology, globalisation and technological performance. Cambridge: Cambridge University Press.

Audretsch, D. B., (1991), 'New-Firm survival and the technological regime.' Review of Economics and Statistics., 60 (3), pp. 441-450.

Audretsch, D. B.,(1995), Innovation and industry evolution. Cambridge: MIT Press.

Barry, F. and J. Bradley, (1997), 'FDI and trade: the Irish host-country experience.' Economic Journal., Vol. 107, pp. 1798-1811.

Beise, M, H. Belitz, and C. Grenzmann, (1998), Indicators for $R \& D$ investment of multinational enterprises. Presented to a joint NESTI/TIP/GSS Workshop on the Internationalisation of R\&D (OECD).

Belitz, H \& M. Beise, (1997), The internationalisation of $R \& D$ in multinational enterprises: the german perspective. London: presented to the National Institute of Economic and Social Research.

Blomström, M and A. Kokko, (1996), 'Multinational corporations and spillovers.' Working Paper Department of Economics, Stockholm School of Economics. No.99.

Braunerhjelm, P. and K. Ekholm, (1997), Foreign activities by multinational corporations. Sweden: Research Institute of Industrial Economics.

Breathnach, M and A. Fitzgerald, (1994), Technological innovation in irish manufacturing industry. Dublin: Forfás.

Cohen, W.M. and D. Levinthal, (1990), 'Absorptive capacity: a new perspective on learning and innovation.' Administrative and Science Quarterly., Vol. 35, pp. 128-152. 
Cox, D.R.,(1972), 'Regression models and life-Tables.' Journal of the Royal Statistical Society., 34, May-August, pp. 187-220.

Cox, D.R., (1975), 'Partial liklihood.' Biometrics., 62(3), pp. 269-275.

CSO, (1997), Census of industrial production 1995. Dublin: Central Statistics Office.

Davis, S.J. and J. Haltiwanger, (1990), Gross job creation, job destruction: microeconomic evidence and macroeconomic implications. NBER Macroeconomics Annual., 5, pp. 123-168.

de Arcos, L., A. Arundel, J. Hagedoorn, , R. Narula, , G. van de Paal, and E. van Sluijs, (1997), Innovative capability, embeddedness and the contribution of foreign firms to innovation in their host regions. EIMS publication by MERIT., No. 44.

Dunning, J. H., (1988), Explaining international production. London: Unwin Hyman.

European Commission, (1991), Eurostatistics: data for short term economic analysis. Eurostat,12.

European Commission, (1997), Eurostatistics: data for short term economic analysis. Eurostat, 6.

Foley, A. and D. McAleese, (1991), Overseas industry in Ireland. Dublin: Gill and Macmillan.

Forfás, (1997), Survey of product and process innovation in Irish industry 1993 - 1995. Dublin: Forfás. 
Gray, A.W., (1997), International perspectives on the Irish economy. Dublin: Indecon.

Killeen, M.J., (1975), 'Contribution to the symposium on increasing employment in Ireland.' Journal of the Statistical and Social Enquiry of Ireland., Vol. XXIII. No. III, pp. 50-64.

Klette, T. J. \& S. E. Forre, (1995), 'Innovation and job creation in a small open economy: evidence from Norwegian manufacturing plants 1982-92.' Statistics Norway, No. 159.

Krugman, P.R., (1997), 'Good news from Ireland: a geographical perspective'. In: Gray, A.W. (ed.): International perspectives on the Irish economy. Dublin: Indecon.

McAleese, D. and D. MacDonald, (1978), 'Employment growth and the development of linkages in foreign-owned and domestic manufacturing enterprises.' Oxford Bulletin of Economics and Statistics., Vol. 40. No. 4, pp. 321-339.

Murphy, A., (1998), The Celtic Tiger - the great misnomer: economic growth and the multi-nationals in Ireland in the 1990's? Dublin: MMI Stockbrokers.

Neven, D and G. Siotis, (1996), 'Technology sourcing and FDI in the EC: An empirical evaluation.' International Journal of Industrial Organisation., Vol.14. No. 5. July 1996.

O'Loughlin, N and P.N. O'Farrell, (1981), 'Foreign direct investment in Ireland: empirical evidence and theoretical implications.' Economic and Social Review., Vol. 11. No.3, pp. 155-185.

OECD, (1996), Employment outlook: July 1996. Paris: OECD.

--(1998), Internationalisation of industrial R\&D: patterns and trends. Paris: OECD.

StataCorp., (1997), Stata statistical software: release 5.0. College Station StataCorp. 
Stewart, J. C.,(1989), 'Transfer pricing: some empirical evidence from Ireland.' Journal of Economic Studies., Vol. 16. No. 3., pp. 40-56.

Stoneman, P., (1995), Handbook of the economics of innovation and technological change. Oxford: Blackwell.

Strobl, E.A, P.P. Walsh, and F. Barry, (1998), 'Aggregate job creation, job destruction and job turnover in the Irish manufacturing sector.' The Economic and Social Review., Vol. 29. No. 1.

Sutton, J., (1991), Sunk costs and market structure. Cambridge: MIT Press.

Walsh, P and J. Konings, (1997), 'The effect of the real exchange rate movements on the life expectancy of manufacturing plants in Ireland, 1973-94.' Trinity Economic Paper., No.7. June 1997.

White, P.A., (1982), 'A concept of industrial development in the 1980s.' Journal of the Statistical and Social Enquiry of Ireland., Vol. XXIV. No. V., pp. 51-59. 